Research article

\title{
Structural analysis of Combretum-Terminalia mixed Acacia vegetation in Ilu Gelan District, West Shewa Zone, Oromia Region, Central Ethiopia
}

\author{
Zerihun Tadesse $^{1,2}$, Ensermu Kelbessa ${ }^{1}$ and Tamrat Bekele ${ }^{1}$ \\ ${ }^{1}$ Department of Plant Biology and Biodiversity Management, the National Herbarium, Addis Ababa University, \\ P.O.Box: 3434, Addis Ababa, Ethiopia \\ ${ }^{2}$ Wollega University, Faculty of Agriculture, Department of Plant Science, Shambu, Ethiopia
}

*Corresponding Author: zerihunbio@gmail.com

[Accepted: 20 April 2018]

\begin{abstract}
Vegetation of two distinct sites known as Dirki and Jato was studied in Ilu Gelan District, West Shewa Zone of Oromia Region, $195 \mathrm{~km}$ west of Addis Ababa, to make a structural analysis on the component plant species comprising the Vegetation. The systematic sampling method was used to collect vegetation data from $54(20 \mathrm{~m} \times 20 \mathrm{~m})$ plots. To collect data for herbaceous plants, five $1 \mathrm{~m} \times 1 \mathrm{~m}$ subplots were laid in each of the main plot, where four were at the corners and one at the center. Diameter at breast height was measured for woody species taller than $2 \mathrm{~m}$ while height and cover/abundance values were visually estimated. Shannon - Wiener Diversity Index was used to calculate species diversity, richness and evenness of the plant communities whereas Soresen's Similarity ratio was used to measure the similarity between the Vegetation and four other related vegetation sites studied earlier in different study areas. One hundred six species were used for the structural analysis of the Vegetation studied. Agglomerative Cluster Analysis revealed three plant community types from the study area. Total density and basal area calculated for woody species were 5,145.83 individuals ha ${ }^{-1}$ and $18.96 \mathrm{~m}^{2} \mathrm{ha}^{-1}$ respectively. Population structure and regeneration status of selected woody species were assessed and results revealed that some species had regeneration problems and need management measures.
\end{abstract}

Keywords: Management measures - Plant community type - Structural analysis.

[Cite as: Tadesse Z, Kelbessa E \& Bekele T (2018) Structural analysis of Combretum-Terminalia mixed Acacia vegetation in Ilu Gelan District, West Shewa Zone, Oromia Region, Central Ethiopia. Tropical Plant Research 5(1): 61-76]

\section{INTRODUCTION}

Being in the geographical coordinates of $3^{\circ} 24^{\prime}$ and $14^{\circ} 53^{\prime}$ North and $32^{\circ} 42^{\prime}$ and $48^{\circ} 12^{\prime}$ East, and possessing a variety of topographical land features like mountains, deep gorges, low lands, valleys and flattened plateaus enabled Ethiopia to be a country of diverse climatic zones. This, in turn, led the country to the possession enormous biodiversity of flora and fauna in Horn of Africa (NBSAP 2005).

As described in Friis (1992), a wide area of Ethiopia was believed to have been covered by vegetation in the past. However, according to Moges et al. 2010, as a result of overpopulation that is being followed by the demand of land for agricultural expansion, the vegetation of Ethiopia shows declining from time to time. Deforestation, which is the main causative agent for the loss of the greater proportion of the biodiversity of the county, is still common in remaining areas (Senbeta \& Tefera 2001).

Consequences of the destruction are currently being pronounced as cycling rate of drought, increasing surface area desertification and declining rate of food supply for all living forms in the country (Moges et al. 2010). These problems are more or less induced on the basis of the pressures exerted on the natural vegetation of the country; and hence need immediate intervention to save further loss of biodiversity in the country. Therefore, this study was done Combretum-Terminalia mixed with Acacia species vegetation Ilu Gelan District to analyze the diversity status, structural organization, and pressure intensity on the vegetation as the whole. 


\section{MATERIALS AND METHODS}

Description of the Study Area

The study was conducted in Ilu Gelan District (Fig. 1), which is situated in Oromia Region about $200 \mathrm{~km}$ from Addis Ababa to the west. The central town of the district is known Ijaji is located at the coordinates of $08^{\circ}$ $59^{\prime} 51^{\prime \prime} \mathrm{N}$ and $037^{\circ} 19^{\prime} 49^{\prime \prime} \mathrm{E}$ with the altitude of $1812 \mathrm{~m}$ a.s.l.

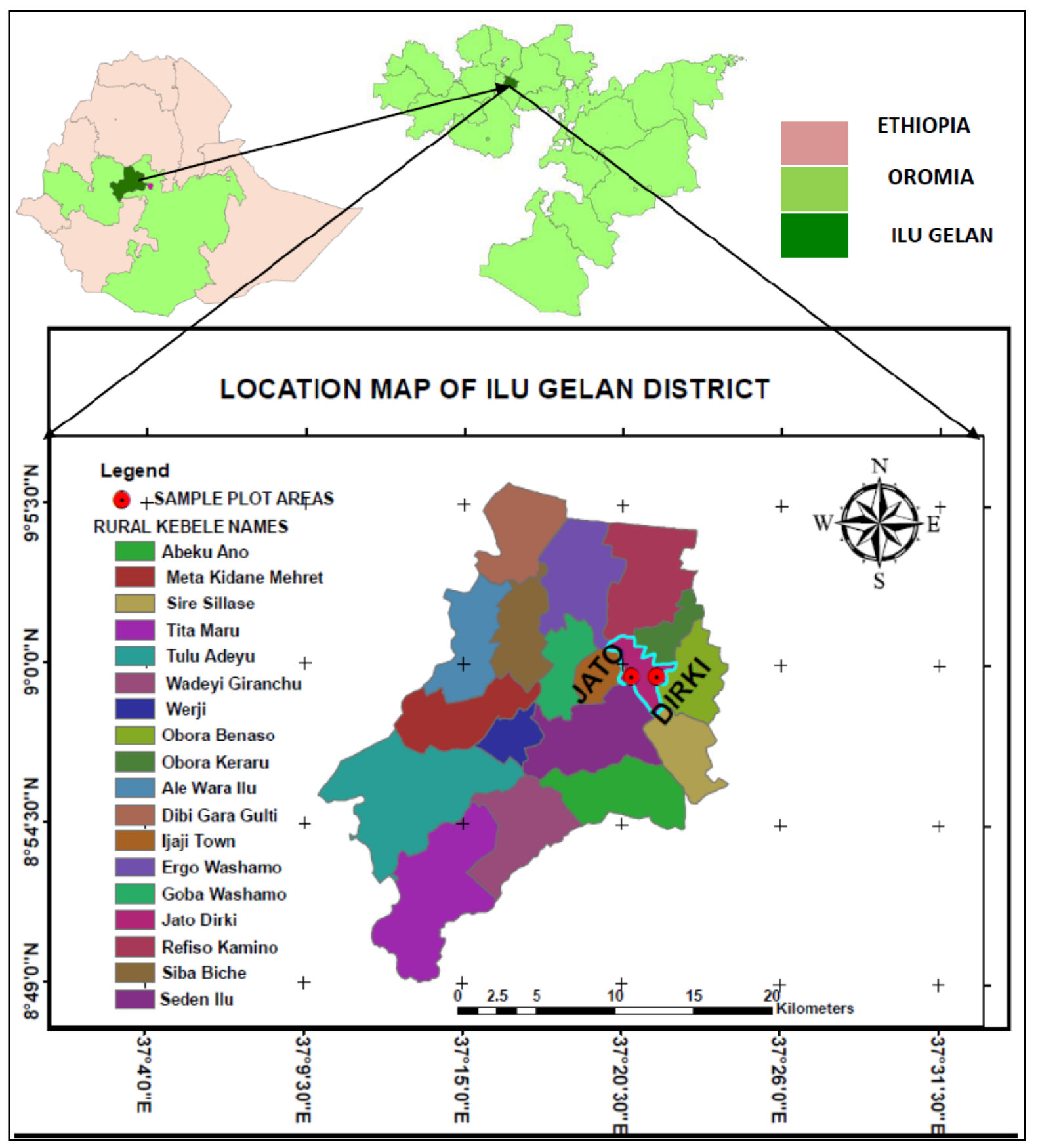

Figure 1. Map of Ethiopia showing the Regional States and the study area.

Climate

The climatic data was obtained from NMA (2015) to draw the climadiagram of the study area for 19952014. It indicates that highest and the lowest annual rainfall recorded in Ilu Gelan was in July and February months, respectively (Fig. 2). Again, the highest temperature was recorded in February while the lowest one was in November.

\section{Sampling Design}

Quadrates of $20 \mathrm{~m} \times 20 \mathrm{~m}$ were laid down along a transect line with the altitudinal drop of $25 \mathrm{~m}$ in the four standard geographical directions to collect data for woody plant species at Dirki site. The same procedure was www.tropicalplantresearch.com 
applied in the case of Jato site in the north and north-west facing directions of the vegetation. Five other smaller $1 \mathrm{~m} \times 1 \mathrm{~m}$ quadrats, one of which was at the center and the rest at the corners were laid in the bigger quadrat to collect data for herbaceous plants.

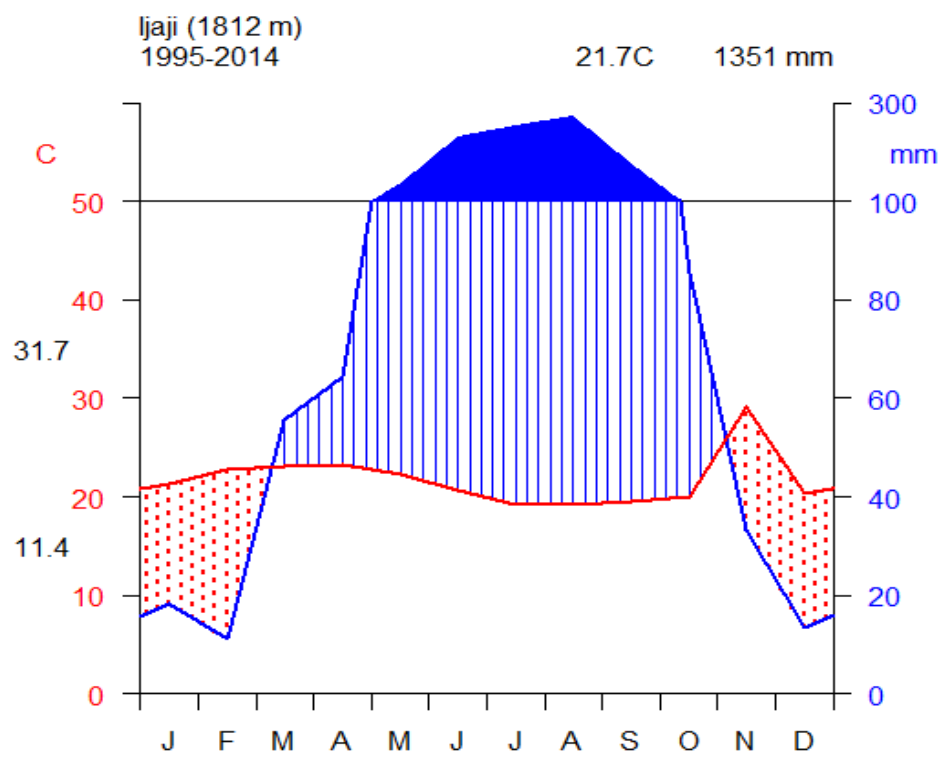

Figure 2. Climadiagram showing rainfall distribution and temperature variation from 1995-2014 around Ijaji Town. [Source: NMA 2015]

\section{Environmental data collection}

Records of altitude, geographical coordinates and aspect were taken in each of the bigger quadrat GPS and Suunnto Compass instruments. The intensity of ecological disturbance was noticed and carefully recorded in the sample plots. To identify the intensity of disturbances from grazing and anthropogenic influences coding system was used like : 0=nil; 1= low; 2= moderate; and 3=heavy, following Woldu \& Backeus (1991), Tekle et al. (1997), Hadera (2000), Yeshitela \& Bekele (2002) and Kidane et al. (2010).

\section{Vegetation data collection}

Vegetation data collection was done for all the plant habit forms (trees, shrubs, lianas, and herbs) obtained inside the sample quadrats. DBH (Diameter at Breast Height) was measured at height of about $1.30 \mathrm{~m}$ above the ground and recorded for all woody species having $\mathrm{DBH} \geq 2 \mathrm{~cm}$ and height $\geq 2 \mathrm{~m}$. In addition to this, estimation of height and cover/abundance values for woody species was made and recorded in the field. If the tree branches at $1.30 \mathrm{~m}$ height or below, the diameter was measured separately for the branches and then averaged.

To assess regeneration status of the vegetation, seedlings and saplings of the woody species encountered in the sample plots were counted. Young plants of woody species having a height less than $0.5 \mathrm{~m}$ were counted as seedlings while those having height in the range of $0.5 \mathrm{~m}$ and $2 \mathrm{~m}$ were counted as saplings.

Cover abundance data defined here as the proportion of area in a quadrat covered by every species recorded and gathered from each quadrat were converted to the 1-9 Braun-Blanquet scale, which was later modified by Van der Maarel (1979) as follows:

1: Rare, generally one individual;

2: Occasional, with less than $5 \%$ cover of the total;

3: Abundant, with less than $5 \%$ cover of the total;

4: Very abundant, with less than $5 \%$ cover of the total;

5: $5-12 \%$ cover of the total area;

6: $12-25 \%$ cover of the total area;

7: $25-50 \%$ cover of the total area;

8: $50-75 \%$ cover of the total area;

9: $75-100 \%$ cover of the total area;

\section{Data Analysis}

\section{Vegetation structure}

Density, DBH and height distribution classes of woody species were used to describe the structure of the Vegetation while IVI was used to describe the ecological importance of some woody species in the study area. 
The density of woody species and basal area of the vegetation were computed on hectare basis. Important value index (IVI) was computed for all woody species based on relative density (RD), relative dominance (RDo) and relative frequency (RF) to determine their dominant position. Analysis of population structure for selected tree species was made on the basis of DBH class distribution to determine their regeneration and recruitment status. Seedlings (SE) and saplings (SA) of tree species were analyzed with their corresponding mature tree (MT) species on density basis to determine the status of their regeneration in the vegetation under the study area.

Importance Value Index (IVI) = Relative Density + Relative Dominance + Relative Frequency

$$
\begin{gathered}
\text { Relative Density }(\mathrm{RD})=\frac{\text { Total number of all individuals of a species }}{\text { Total numbers of individuals of all species }} \times 100 \\
\text { Relative Dominance }(\mathrm{RDo})=\frac{\text { Total basal area of a species }}{\text { Total basal area of all the species }} \times 100 \\
\text { Relative Frequency }(\mathrm{RF})=\frac{\text { Number of quadrats in which a species occurs }}{\text { Total number of quadrats examined }} \times 100
\end{gathered}
$$

Basal area (BA) will be calculated using $\mathrm{DBH}$ as: $\mathrm{BA}=\pi \mathrm{d}^{2} / 4$

$$
\text { where, } \pi=3.14 \text {; } \mathrm{d}=\mathrm{DBH}(\mathrm{m}) \text {. }
$$

Canonical Correspondence Analysis (CCA) is an important parameter used to analyze the relationship between environmental variables and vegetation data (Kassa et al. 2016). In this study, CCA was done to explore the relationship between the environmental variables and vegetation data by fitting the data into ordination scatter plot using the book in preparation (Woldu 2012).

2. Diversity analysis

Shannon -Wiener Diversity Index was used to analyze the species diversity, species richness and evenness of the vegetation as:

Where H: Shannon-Wiener Index.

$$
\mathrm{H}=-\sum P i \operatorname{In} P i
$$

$P i$ : the proportion of individual tree species.

$\ln : \log$ base $_{\mathrm{n}}$

The equitability or evenness of the species in each quadrat was computed using the formula:

$$
\text { Equitability (Evenness) } \mathrm{J}=\frac{H^{\prime}}{H_{\max }}=\sum_{i=1}^{S} \frac{P i \ln P i}{\ln S}
$$

Where S: the number of species

$\mathrm{Pi}$ : the proportion of individuals of the $\mathrm{i}^{\text {th }}$ species or the abundance of the $\mathrm{i}^{\text {th }}$ species expressed as a proportion of total cover

ln: log base

\section{Phytogeographical similarity}

Sorenson's Similarity ratio was used to evaluate the similarity between the three plant community types of the vegetation in the study area and as well as the similarity between Dirki and Jato Vegetation, and four other previously studied woodlands on the basis of their species composition.

Where Ss: Sorensen's similarity coefficient

$$
S s=\frac{2 a}{2 a+b+c}
$$

a: number of species common to both samples /communities/ study areas

b: number of species in sample 1

c: number of species in sample 2

\section{RESULTS}

Stem density

Species were classified into five density classes as: $A=>100 ; B=50.1-100 ; C=10.1-50 ; D=1.1-10 ; E=<1$. The total stem density calculated for individuals of woody species with DBH $\geq 2 \mathrm{~cm}$ was $5145.83 \mathrm{ha}^{-1}$ (Table 1 ). www.tropicalplantresearch.com 
Seventeen species contributed $80.09 \%$ of the total density from the density class A where Clausena anisata, Maytenus arbutifolia, Calpurnia aurea and Premna schimperi constituted 15.99\%, 9.59\%, 6.96\% and 6.93\% respectively. Eighteen species from the density class E constituted only $0.22 \%$ of the total density. Brucea antidysenterica, Buddleja polystachya, Clematis longicauda, Ficus vasta, Phoenix reclinata, Ricinus communis and Rubus apetalus contributed $0.13 \%$ while the rest eleven species of this density class constituted $0.09 \%$ of the total density.

Table 1. Stem density ha ${ }^{-1}$ distribution of woody plants in different density classes.

\begin{tabular}{|c|c|c|c|c|}
\hline Density class & Number of species & Number of stems & Stem density ha $^{-1}$ & $\%$ density \\
\hline $\mathrm{A}$ & 17 & 8902 & 4121.30 & 80.09 \\
\hline B & 5 & 689 & 318.98 & 6.20 \\
\hline $\mathrm{C}$ & 20 & 1147 & 531.02 & 10.32 \\
\hline $\mathrm{D}$ & 34 & 352 & 162.96 & 3.17 \\
\hline $\mathrm{E}$ & 18 & 25 & 11.57 & 0.22 \\
\hline Total & 94 & $\mathbf{1 1 , 1 1 5}$ & $5,145.83$ & 100 \\
\hline
\end{tabular}

DBH distribution

Density distribution of individuals of woody species showed decreasing from lower to higher DBH classes (Table 2). Most of the species had the highest number of individuals in the lowest DBH class and proceeding with decreasing degree to the consecutive higher DBH classes. DBH classes: $1=2.0-4.0 \mathrm{~cm}, 2=4.0-6.0 \mathrm{~cm}, 3=$ $6.0-10.0 \mathrm{~cm}, 4=10.0-20.0 \mathrm{~cm}, 5=20.0-30.0 \mathrm{~cm}, 6=30.0-40.0 \mathrm{~cm}, 7=40.0-50.0 \mathrm{~cm}, 8=>50 \mathrm{~cm}$.

Table 2. Density ha ${ }^{-1}$ distribution of woody individuals in different DBH classes.

\begin{tabular}{lrrr}
\hline DBH Class $(\mathbf{c m})$ & Above ground stem & Density ha & \\
\hline$<10$ & 10742.00 & 4973.15 & \% density ha $^{-1}$ \\
$10.1-20.0$ & 231.00 & 106.94 & 96.64 \\
$20.1-30.0$ & 69.00 & 31.94 & 2.08 \\
$30.1-40.0$ & 38.00 & 17.59 & 0.62 \\
$40.1-50.0$ & 22.00 & 10.19 & 0.34 \\
$>50$ & 13.00 & 6.02 & 0.20 \\
\hline Total & $\mathbf{1 1 , 1 1 5}$ & $\mathbf{5 , 1 4 5 . 8 3}$ & 0.12 \\
\hline
\end{tabular}

\section{Height class distribution}

Individuals of woody species were classified into six height classes (Table 3) and density ha ${ }^{-1}$ was calculated on this basis. Highest density $\mathrm{ha}^{-1}(93.19 \%)$ was recorded in the lowest height class while in the second height class, density ha ${ }^{-1}$ was found to be $5.31 \%$. The calculated densities for the remaining four height classes were also $0.56 \%, 0.60 \%, 0.23 \%$ and $0.11 \%$ respectively.

Table 3. Density ha ${ }^{-1}$ of woody individuals in different height classes.

\begin{tabular}{|c|c|c|c|}
\hline Height class (m) & Aboveground stems & Density ha $^{-1}$ & $\%$ density ha ${ }^{-1}$ \\
\hline $2.0-6.0$ & 10358 & 4795.37 & 93.19 \\
\hline $6.1-10.0$ & 590 & 273.15 & 5.31 \\
\hline $10.1-14.0$ & 62 & 28.70 & 0.56 \\
\hline $14.1-18.0$ & 67 & 31.02 & 0.60 \\
\hline $18.1-22.0$ & 26 & 12.04 & 0.23 \\
\hline$>22$ & 12 & 5.50 & 0.11 \\
\hline Total & 11,115 & $5,145.83$ & 100 \\
\hline
\end{tabular}

Frequency

Results from the computed frequency values of different species were classified into five frequency classes as:

$$
\mathrm{A}=1.0-20.0, \mathrm{~B}=20.1-40.0, \mathrm{C}=40.1-60.0, \mathrm{D}=60.1-80.0, \mathrm{E}=80.1-100 \text { (Fig. 3). }
$$

The result showed that $60.64 \%$ of the total woody species were distributed in the lowest frequency class one whereas, in the next four consecutive frequency classes, $12.77 \%, 14.89 \%, 3.19 \%$ and $8.51 \%$ of the species were distributed respectively.

The eight most frequent species (Table 4) in the vegetation studied were Premna schimperi (96.30\%), Calpurnia aurea (94.44\%), Maytenus arbutifolia (92.59\%), Carissa spinarum (87.4\%), Grewia ferruginea (87.04\%), Clausena anisata (83.33\%), Croton macrostachyus (83.33\%) and Searsia natalensis (81.48). 


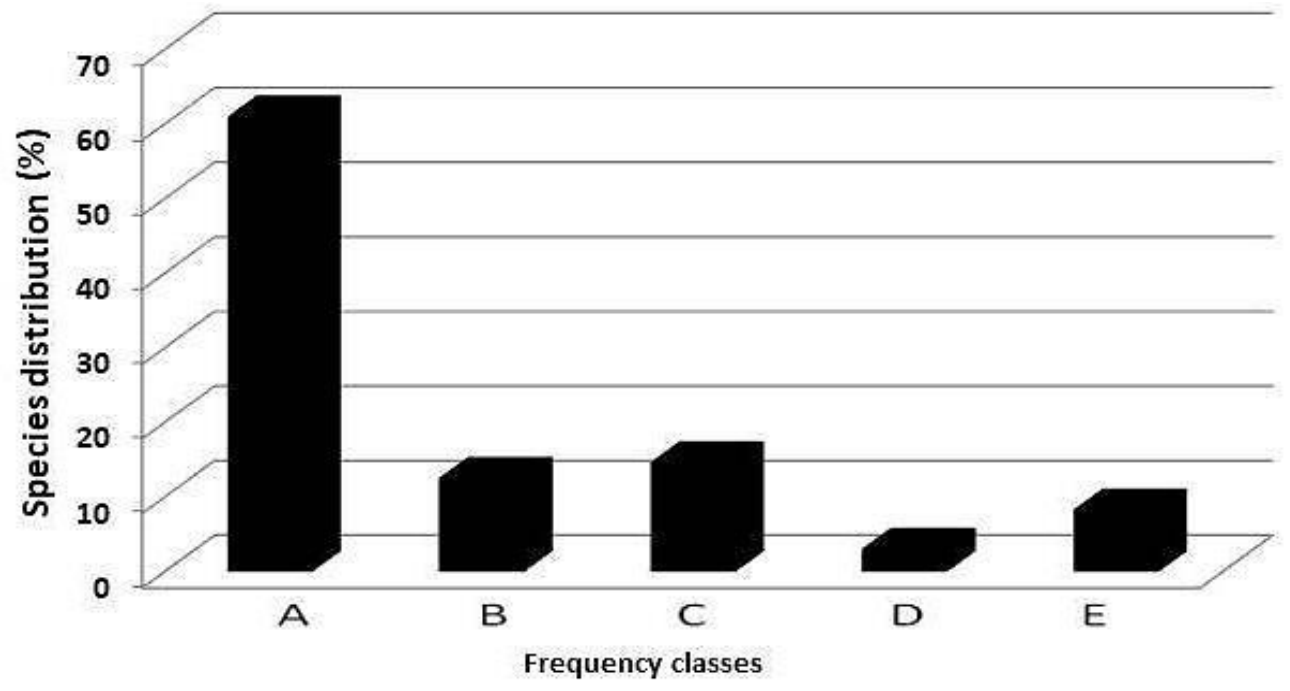

Figure 3. Frequency distribution for woody species in Dirki and Jato Vegetation.

Table 4. Top 25 most frequent woody species in the study area.

\begin{tabular}{lr}
\hline Species & \% of Frequency \\
\hline Premnas chimperi Engl. & 96.30 \\
Calpurnia aurea (Ait.) Benth. & 94.44 \\
Maytenus arbutifolia (A.Rich.) Wilczek & 92.59 \\
Carissa spinarum L. & 87.04 \\
Grewia ferruginea Hochst. ex A. Rich & 87.04 \\
Clausena anisata (Willd). Benth. & 83.33 \\
Croton macrostachyus Del. & 83.33 \\
Searsia natalensis (Bernh. ex Krauss) F.A Barkley & 81.48 \\
Albizia schimperiana Oliv. & 75.93 \\
Bersama abyssinica Fresen. & 64.81 \\
Searsia pyroides (Burch.) Moffett. & 64.81 \\
Acacia abyssinica Hochst. ex Benth & 59.26 \\
Maesa lanceolata Forssk. & 59.26 \\
Syzygium guineense (Willd.) DC. & 59.26 \\
Combretum molle R. Br. ex G.Don & 57.41 \\
Rytigynia neglecta (Hiern) Robyns & 57.41 \\
Ssyris lanceolata Hochst. \&Steud & 55.56 \\
Vangueria apiculata K. Schum. & 51.85 \\
Senna petersiana (Bolle) Lock & 50.00 \\
Euclea divinorum Hien & 44.44 \\
Phyllanthus ovalifolius Forssk. & 44.44 \\
Pterolobium stellatum (Forssk.) Brenan & 44.44 \\
Stereospermum kunthianum Cham. & 44.44 \\
Flacourtia indica (Burm.f.) Merr & 42.59 \\
Olinia rochetiana A.Juss. & 42.59 \\
\hline
\end{tabular}

\section{Basal Area}

Total basal area of the vegetation was $18.95 \mathrm{~m}^{2} \mathrm{ha}^{-1}$ for woody species $>2 \mathrm{~cm}$ in DBH and $>2 \mathrm{~m}$ in height (Table 5). It was $7.87 \mathrm{~m}^{2} \mathrm{ha}^{-1}$ for individuals $2.0-10.0 \mathrm{~cm}, 1.67 \mathrm{~m}^{2} \mathrm{ha}^{-1}$ for individuals $10.1-20.0 \mathrm{~cm}$ and 9.41 $\mathrm{m}^{2} \mathrm{ha}^{-1}$ for individuals $\geq 20 \mathrm{~cm}$ in DBH respectively. Ficus vasta, Acacia abyssinica, Croton macrostachyus, Syzygium guineense subsp. guineense, Clausena anisata, Cordia africana, Combretum molle, Albizia schimperiana, Maesa lanceolata and Sapium ellipticum constituted $60.46 \%$ of the total basal area.

Table 5. Basal area of woody species within different DBH classes.

\begin{tabular}{lrrr}
\hline DBH $(\mathbf{c m})$ & Aboveground stem & Basal area ha $^{-1}$ & \% Basal area \\
\hline $2.0-10.0$ & 10,742 & 7.87 & 41.53 \\
$10.1-20.0$ & 231 & 1.67 & 8.81 \\
$>20$ & 142 & 9.41 & 49.66 \\
\hline Total & $\mathbf{1 1 , 1 1 5}$ & $\mathbf{1 8 . 9 5}$ & $\mathbf{1 0 0}$ \\
\hline
\end{tabular}


Importance Value Index (IVI)

Data obtained from the analysis of relative density (RD), relative frequency (RF) and relative dominance (RDo) was used to calculate the importance value index (IVI) of the vegetation (Table 6).Twenty one (22.11\%) woody species having IVI greater than 5 constituted 221.18 (73.73\%) from the total 300 . Accordingly, the top 15 ecologically most dominant woody species in Dirki and JatoVegetation are Clausena anisata, Maytenus arbutifolia, Premna schimperi, Acacia abyssinica, Ficus vasta, Calpurnia aurea, Croton macrostachyus, Syzygium guineense subsp. guineense, Searsia natalensis, Maesa lanceolata, Carissa spinarum, Albizia schimperiana, Grewia ferruginea, Bersama abyssinica and Combretum molle. These, in turn, constituted 186.71 $(62.24 \%)$ of the total 300 IVI of the vegetation studied.

Table 6. Relative Density, Relative Frequency, Relative Dominance and IVI of top 21 woody species in Dirki and Jato Vegetation.

\begin{tabular}{rlrrrr}
\hline S/N & Species & RD & RF & RDo & IVI \\
\hline 1 & Clausena anisata (Willd). Benth. & 15.99 & 3.56 & 4.77 & 24.32 \\
2 & Maytenus arbutifolia (A.Rich.) Wilczek & 9.59 & 3.96 & 3.11 & 16.66 \\
3 & Premna schimperi Engl. & 6.93 & 4.12 & 2.81 & 13.85 \\
4 & Acacia abyssinica Hochst. ex Benth & 0.98 & 2.53 & 10.08 & 13.59 \\
5 & Ficus vasta Forssk. & 0.02 & 0.16 & 13.07 & 13.25 \\
6 & Calpurnia aurea (Ait.) Benth. & 6.96 & 4.04 & 2.24 & 13.24 \\
7 & Croton macrostachyus Del. & 2.07 & 3.56 & 6.55 & 12.18 \\
8 & Syzygium guineense (Willd.) DC. & 3.99 & 2.53 & 5.43 & 11.95 \\
9 & Searsia natalensis (Bernh. ex Krauss) F.A Barkley & 4.78 & 3.48 & 3.21 & 11.48 \\
10 & Maesa lanceolata Forssk. & 4.79 & 2.53 & 3.84 & 11.16 \\
11 & Carissa spinarum L. & 4.59 & 3.72 & 1.88 & 10.19 \\
12 & Albizia schimperiana Oliv. & 2.22 & 3.25 & 4.28 & 9.75 \\
13 & Grewia ferruginea Hochst.ex A. Rich. & 3.89 & 3.72 & 1.81 & 9.42 \\
14 & Bersama abyssinica Fresen. & 3.06 & 2.77 & 2.02 & 7.85 \\
15 & Combretum molle R. Br. ex G.Don & 1.05 & 2.45 & 4.32 & 7.82 \\
16 & Searsia pyroides (Burch.) Moffett. & 2.10 & 2.77 & 1.57 & 6.44 \\
17 & Osyris lanceolata Hochst. \& Steud & 2.56 & 2.38 & 1.39 & 6.33 \\
18 & Olinia rochetiana A.Juss. & 2.49 & 1.82 & 1.73 & 6.04 \\
19 & Cordia africana Lam. & 0.24 & 0.71 & 4.49 & 5.45 \\
20 & Rytigynia neglecta (Hiern) Robyns & 2.02 & 2.45 & 0.62 & 5.10 \\
21 & Millettia ferruginea (Hochst.) Bak. & 2.07 & 1.11 & 1.92 & 5.10 \\
\hline
\end{tabular}

Dominance

Because of the relative ecological roles they play in the vegetation area, twentyone tree/and or shrub species were selected as dominant species in the vegetation (Table 5). Clausena anisata, Maytenus arbutifolia, Premna schimperi, Acacia abyssinica, Ficus vasta, Calpurnia aurea, Croton macrostachyus, Syzygium guineense subsp. guineense, Searsia natalensis, Maesa lanceolata, Carissa spinarum, Albizia schimperiana, Grewia ferruginea, Bersama abyssinica, Combretum molle, Searsia pyroides, Osyris lanceolata, Olinia rochetiana, Cordia africana, Rytigynia neglecta and Millettia ferruginea were dominant species in the vegetation.

Population structure of selected tree species in the Vegetation

The analysis of selected woody species in the study area resulted in six different patterns of population structures, and one species was taken to show its corresponding pattern (Fig. 4). The first population pattern was represented by species distributed only in the DBH class one and totally absent from the other DBH classes (Fig. 4A). Calpurnia aurea was taken as representative species in this pattern. The other species showing this pattern were Allophylus macrobotrys, Apodytes dimidiata, Bridelia micrantha, Buddleja polystachya, Capparis tomentosa, Ehretia cymosa, Ekebergia capensis, Dalbergia lacteal, Diospyros abyssinica, Dovyalis abyssinica, Flacourtia indica, Ficus sycomorus, Ficus thonningii, Maytenus obscura, Pterolobium stellatum, Rothmannia urcilliformis and Vernonia amygdalina.

The second population pattern was represented by species having the highest density in the first DHH class, and then decreasing and ending in the DBH class two or three (Fig. 4B). Species showing this pattern were Clausena anisata, Dodonaea angustifolia, Euclea divinorum, Grewia ferruginea, Maytenus arbutifolia, Maesa laceolata, Olea europaea subsp. cuspidata, Osyris lanceolata, Searsia natalensis, Searsia pyroides, Sapium ellipticum, Schrebera alata, Terminalia macroptera, Vangueria apiculata and, Bersama abyssinica (the species taken as representative to show the pattern). 

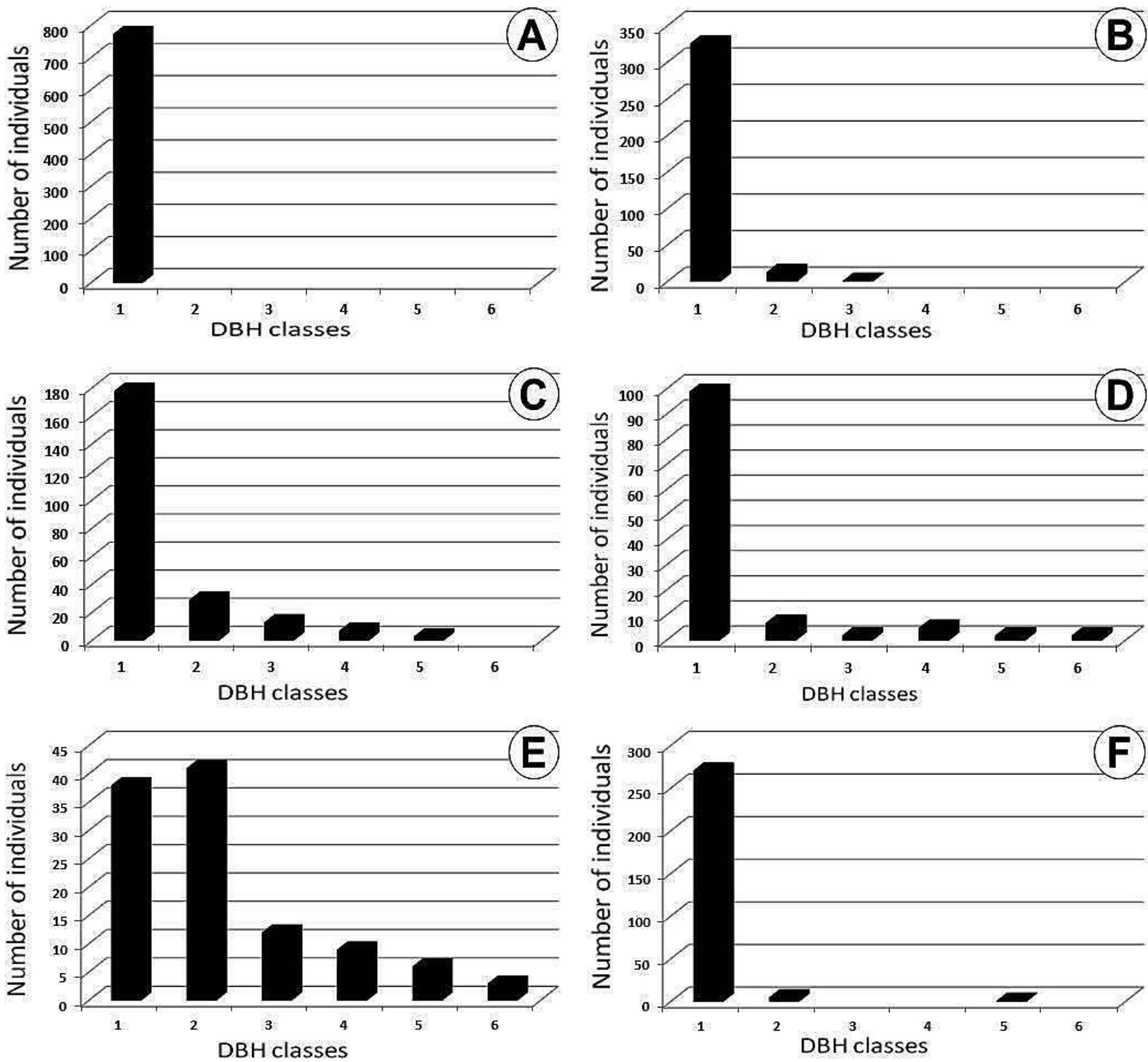

Figure 4. Population patterns of Dirki and Jato Vegetation: A, Calpurnia aurea; B, Bersama abyssinica; C, Crotom macrostachyus; D, Combretum molle; E, Acacia abyssinica; F, Olinia rochetiana. (DBH classes: $1=<10 \mathrm{~cm}, 2=10.1-20.0$ $\mathrm{cm}, 3=20.1-30.0 \mathrm{~cm}, 4=30.1-40.0 \mathrm{~cm}, 5=40.1-50.0 \mathrm{~cm}, 6=>50 \mathrm{~cm}$ )

The third population pattern represented by Crotom macrostachyus was shown by the species having relatively the highest density in the DBH class one and decreasing towards the higher DBH classes and then ending in the DBH class three or four (Fig. 4C). Species showing this pattern were Ficus sur, Millettia ferruginea and Stereospermum kunthianum.

The fourth population pattern was represented by the species which had the highest density in the DBH class one and decreasing towards the highest DBH class (Fig. 4D). This population pattern was represented in all the DBH classes. Species showing this pattern were Combretum molle, Albizia schimperiana and Syzygium guineense subsp. guineense. Combretum molle was taken to represent the population structure shown by the species.

The fifth population pattern was shown by the species having the highest density in the DBH class two and relatively higher density of individuals in the first DBH class, but decreasing towards the higher DBH classes (Fig. 4E). Acacia abyssinica and Ficus mucuso showed this population pattern. But in the first DBH class, density was not far apart from the highest density recorded in the DBH class two, whereas it was gradually decreasing towards the higher classes.

The sixth population pattern represented by Olinia rochetiana was shown by species having relatively the highest density in the DBH class one and decreasing through interruptions towards the higher DBH classes (Fig. 4F). Species showing this pattern were Carissa spinarum, Celtis africana, Cordia africana, Dombeya torrida, Ficus vasta, Olinia rochetiana, Podocarpus falcatus, Premna schimperi, Rytigynia neglecta and Senna petersiana. 
Regeneration Status: Composition and density of seedlings and saplings

Seedlings and saplings of sixty mature tree species were used to describe the regeneration status of the vegetation. Total density of seedlings, saplings and mature tree species were 4,790.28 $\mathrm{ha}^{-1}, 4219.91 \mathrm{ha}^{1}$ and 4685.18 $\mathrm{ha}^{-1}$ respectively (Appendix 1).

Three species groups were obtained from the sixty tree species that were analyzed based on presence/absence of seedlings and saplings, comparing the total number of the seedlings and saplings together with the total number of the corresponding mature tree species. Fourteen (23.33\%) species categorized under the first group were not represented by seedlings and saplings. Acacia abyssinica, Apodytes dimidiata, Cordia africana, Ficus mucuso, Ficus sur, Mimusops kummel, Prunus africana and Rothmannia urcelliformis were some of the species showed this condition. Twentytwo (36.67\%) species categorized under the second group were represented by less sum total of seedlings and saplings than the mature trees. The species showed this status were Albizia schimperiana, Allophylus macrobotrys, Bersama abyssinica, Celtis africana, Croton macrostachyus, Dalbergia lacteal, Ehretia cymosa and Grewia ferruginea. The rest 24 (40\%) species put under the third group were represented by more sum total of seedlings and saplings than the mature trees in the vegetation. Species like Bridelia micrantha, Calpurnia aurea, Clausena anisata, Combretum paniculatum, Dodonaea angustifolia, Dombeya torrida, Dovyalis abyssinica, Euclea divinorum and Flacourtia indica were represented by this behaviour.

\section{Phytogeographical condition of Dirki and Jato Vegetation}

The vegetation of Dirki and Jato in Ilu Gelan District has been compared with four other relatively related woodlands studied at different times. These woodlands are found around Lake Abaya to Chencha highlands between the altitudinal range of 1177-2718 m a.s.l. (Wana 2002), GamoGofa between the altitudinal range of 600-1900 m a.s.1. (Soromessa et al. 2004), Koga irrigation between the altitudinal range of 1894-2344 m a.s.1. (Mekonnen 2009) and Gilgel Gibe III between the altitudinal range of 703-828 m a.s.l. (Adugna 2010). The first two and fourth studies were conducted in southern Ethiopia while the third one was done in the northwest part of the country. The species richness of these four woodlands was compared with that of Dirki and jato to determine the phytogeographical impression of the study area (Table 7).

Table 7. Comparison of the vegetation of Dirki and Jato with other woodland vegetations studied in Ethiopia.

\begin{tabular}{llrrrr}
\hline Woodlands & Reported by & a & b & c & Sc \\
\hline Lake Abaya to Chencha & Desalegn Wana (2002) & 43 & 170 & 132 & 0.222 \\
GamoGofa & Teshome Soromessa et al. (2004) & 27 & 186 & 189 & $\mathbf{0 . 1 2 6}$ \\
Koga irrigation area & Amare Mekkonen (2009) & 35 & 178 & 36 & $\mathbf{0 . 2 4 6}$ \\
Gilgel Gibe III area & Fisseha Adugna (2010) & 20 & 193 & 66 & 0.134 \\
\hline
\end{tabular}

Where, $\mathbf{a}=$ Species common to Dirki and Jato Woodlands, and the woodland in comparison.

$\mathbf{b}=$ Species unique to the vegetation of Dirki and Jato vegetation.

$\mathbf{c}=$ Species found only in the vegetation in comparison with Dirki and Jato vegetation.

Sc $=$ Sorensen's Similarity Coefficient.

Impacts of environmental variables on vegetation distribution

The relationship between vegetation data and environmental variables, as well as among the environmental variables themselves (such as altitude, aspect, human impacts and grazing) was calculated through fitting them onto CCA ordination scatterplots (Fig. 5). The result from the analysis indicates that the ecological disturbances from anthropogenic and grazing impacts are more deteriorating the Vegetation than the other factors. Northfacing aspect of the vegetation particularly in case of Dirki was less influenced by grazing as compared to the other aspects. However, since anthropogenic impacts are more or less associated with the whole vegetation, the variance is not markedly indicated. However, the effects of cutting trees and shrubs, collecting fuelwood and producing charcoal are well noticed as the main anthropogenic pressures on the vegetation of the study area (Fig. 5).

\section{DISCUSSION}

Density of woody species

Result from the analysis of the vegetation data shows that most proportion of the stem density is contributed by woody species having stem density in the density class greater than 100 (Density size class: $\mathrm{A}=>100 ; \mathrm{B}=$ 50.1-100; $\mathrm{C}=10.1-50 ; \mathrm{D}=1.1-10 ; \mathrm{E}=<1)$. Only 17 (18.09\%) woody species having many aboveground stems constituted $4121.30 \mathrm{ha}^{-1}(80.09 \%)$ of the total density of the Vegetation. The five density wise most dominant www.tropicalplantresearch.com 
plant species found in this class are Clausena anisata $822.69 \mathrm{ha}^{-1}(15.99 \%)$, Maytenus arbutifolia 493.52 ha $^{-1}$ (9.59\%), Calpurnia aurea $358.33 \mathrm{ha}^{-1}$ (6.96\%), Premna schimperi $356.48 \mathrm{ha}^{-1}(6.93 \%)$ and Maesa lanceolata $246.30 \mathrm{ha}^{-1}(4.79 \%)$. This result is similar to the finding of the study done by Kebede (2010), as few individuals cover the most proportion of the density classes of vegetation under secondary regeneration. However, stem density of 18 woody species with the density class less than one is only $11.57 \mathrm{ha}^{-1}(0.22 \%)$. This indicates that the species are scarcely represented by 1-2 individuals in the vegetation.

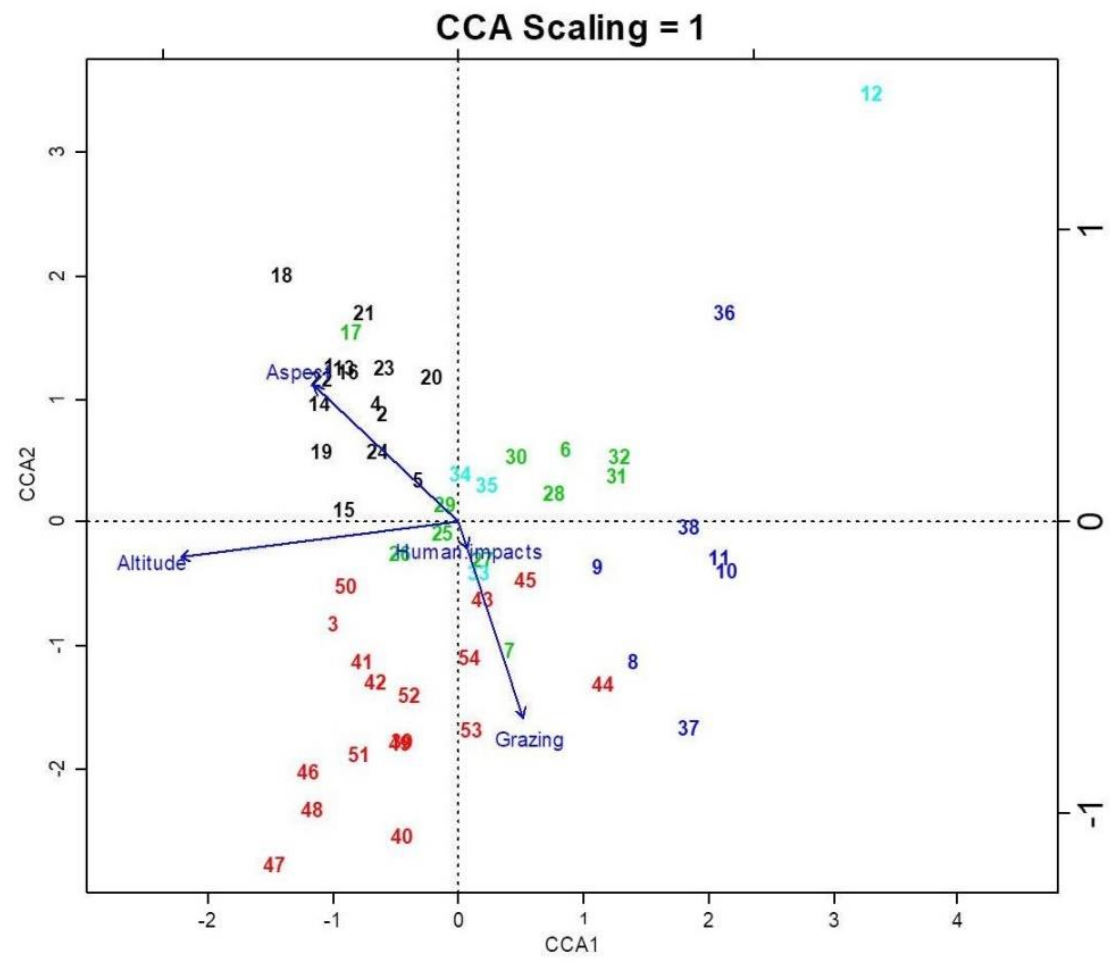

Figure 5. Impact of altitude, Aspect and grazing on Dirki and Jato Vegetation.

\section{DBH and height classes}

The distribution of density ha ${ }^{-1}$ of individuals of woody species showed decreasing from lowest DGH class to the higher DBH classes. More than $96 \%$ of the density of the woody species is distributed in the lowest DBH class $<10 \mathrm{~cm}$ which shows that most proportion of the vegetation is represented by shrubs and small trees. However, as the DBH class increased, density was decreasing, that means, the vegetation has a small number of big trees in the higher DBH classes as compared to shrubs and small trees concentrated in the lower DBH classes. This pattern indicates that Dirki and Jato Vegetation have good natural reproduction and recruitment potential. Similar results were reported by Yeshitela \& Bekele (2003), Ayalew et al. (2006), Senbeta (2006) and Enkossa (2008). Most woody plants that could grow to big trees might have also been cut at early stage. This indicates that the Vegetation has been under anthropogenic influences.

Like the DBH class distribution, a large proportion of the density $\mathrm{ha}^{-1}(93.19 \%)$ of the sampled woody plants is distributed in the lowest height class one. This result is similar to the findings of the study done by Abdena (2010) and Dibaba et al. (2014). With increasing height classes, density $\left(\right.$ ha $^{-1}$ ) of the woody plants continued decreasing except the interruptions shown at the $3^{\text {th }}$ and $4^{\text {th }}$ height classes. The interruptions shown in density distribution at these height classes could be attributed tocut effect that might have exerted on the plants at the certain development stage. Only a few individual trees $(0.11 \%$ of the total) were recorded in the highest height class (> $22 \mathrm{~m}$ ). This indicates that the vegetation of Dirki and Jato can be categorized under secondary regeneration, i.e., most primary plants could be cut before growing into big trees. As a result, secondary young plants can regenerate and replace the primary generation.

\section{Frequency}

The result from frequency distribution showed that the highest number $(60.64 \%)$ of the total species is distributed in the lowest frequency class $\mathrm{A}$, and few $(8.51 \%)$ species are distributed in the highest frequency class $\mathrm{E}$ while other species are distributed in between the two marginal frequency classes. Species in the lowest frequency class were relatively recorded from few sample plots whereas those in the highest frequency class 
were the most frequent ones recorded from several sample plots. Premna schimperi, Calpurnia aurea, Maytenus arbutifolia, Carissa spinarum, Grewia ferruginea, Clausena anisata, and Croton macrostachyus have shown the highest values of relative frequency which indicates that these species have relatively good distribution status in the vegetation. Few woody species having the highest frequency value took the dominant position in the Vegetation, and this situation is also in line with Kidane et al. (2010).
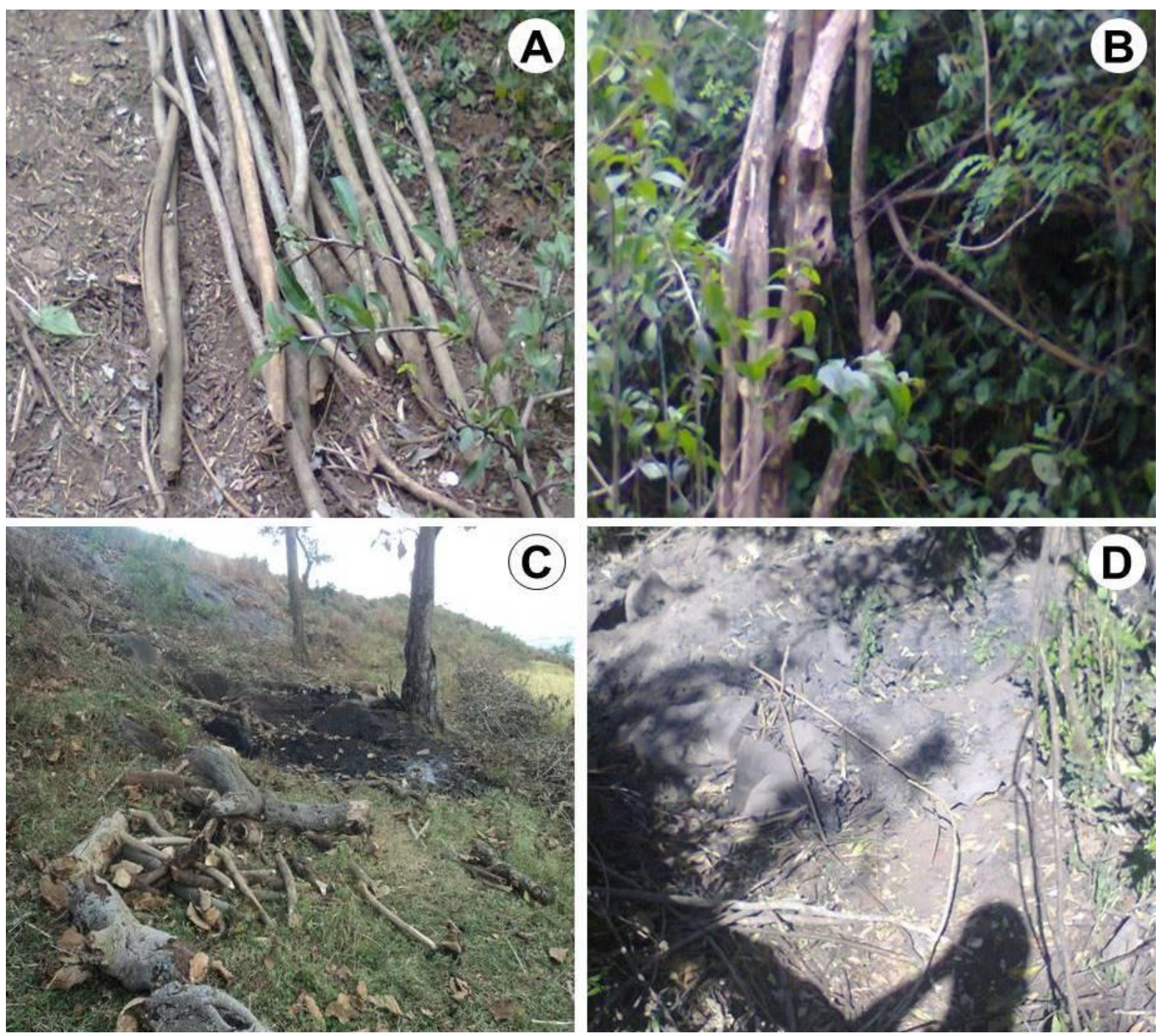

Figure 6. Effects of human pressures on the vegetation (a-b cutting effect and c-d charcoal production).

Importance Value Index

Data obtained from Relative Frequency, Relative Density and Relative Basal Area to calculate Importance Value Index (IVI) of woody species. IVI is a useful parameter to make a comparison of the ecological significance of species (Lamprecht 1989).

The most top ten species having the highest IVI in the Vegetation were Clausena anisat, Matenus arbutifolia, Premna schimperi, Aacacia abyssinica, Ficus vasta, Calpurnia aurea, Croton macrosthachyus, Syzygium guineense subsp. Guineense, Searsia natalensis and Maesa lanceolata. Species like and Ficus vasta are ecologically more important in one community while other species such as Clausena anisata, Calpurnia aurea and Maytenus arbutifolia are distributed relatively in more than one community and ecologically play more important roles than the species restricted to one community type.

Analysis of the Importance Value Index (IVI) of the Vegetation indicated that $21(22.34 \%)$ of the total woody species have IVI greater than 5.00 and constitute 221.18 (73.73\%) of the total 300 IVI of the vegetation. Clausena anisata, Maytenus arbutifolia, Premna schimperi, Acacia abyssinica, Ficus vasta, Calpurnia aurea and Croton macrostachyus are the species relatively having higher IVI than the rest of the species. The highest relative density of Clausena anisata and Maytenus arbutifolia attributed to their highest IVI positionwhile the IVI of Ficus vasta was contributed from the highest value of its basal area. 
Population structures of selected trees and shrubs

Population structures of trees have significant implications for their management, sustainable use and conservation strategies (Shibru \& Balcha 2004, Bajpai et al. 2015). Population pattern is helpful to understand the population density, regeneration and recruitment status of particular vegetation (Teketay 2005, Alemu 2011). Based on this concept, six population patterns of tree species were observed from the data analyzed.

The first population pattern represented by Calpurnea aurea as shown in (Fig. 4A), indicates that all individuals of the species were distributed in the DBH class one and totally absent from the higher DBH classes. This might be attributed to shrubby nature of the species or cutting effects practiced on trees before growing to big size. Even though this was the case, this population pattern indicates the vegetation has good reproduction and recruitment capacity (Demise et al. 2013).

The second population pattern represented by Bersama abysinica (Fig. 4B) was represented by species having the highest frequencies of individuals in the first DBH class and then ending in the DBH class two. This pattern is related to the first population structure but shows relatively inverted J-shape which indicates as the vegetation is in good regeneration and recruitment status (Yineger et al. 2008).

The third population structure was shown in (Fig. 4C) and represented by Croton macrostachyus. In this pattern, the highest frequencies of individuals of the species were distributed in the DBH class one. Species represented in the population pattern showed a gradual decrease and become less frequent towards the higher DBH classes. This pattern indicates also good regeneration status of the Vegetation.

The fourth population pattern was indicated in (Fig. 4D) and represented by Combretum molle. The highest frequency was relatively distributed in the DBH class one and then shown gradual decline towards the highest DBH class. This indicates that the Vegetation is in a good regeneration status.

In the fifth population pattern represented by Acacia abyssinica (Fig. 4E), higher frequencies of individuals of the species were observed in the DBH class two and decreasing towards the higher DBH classes. It indicates the Vegetation has good regeneration and recruitment capacity of species as relatively few numbers of individuals are present in the higher DBH classes than in the lower classes (Bekele 1993, Senbeta 2006, Demise et al. 2013). This structure indicates good regeneration and recruitment status of the woody species represented by this population pattern.

The sixth population pattern represented by Olinia rochetiana as shown in (Fig. 4F), was represented by species having the highest frequencies of individuals in the first DBH class and then showed gradual decrease towards the higher DBH classes. However, representative individual species were not recognized in some DBH class distributions of this population structure. This might be because of cutting effects exerted on selective species at certain important development age by the local communities. Even though this is the case, this population pattern shows a good reproduction and recruitment status of the species (Yineger et al. 2008).

\section{Regeneration status of the woodland vegetation}

According to Denu (2006), regeneration status of any vegetation can be explained on the basis of number and type of seedlings and saplings associated with that vegetation. Comparison of total densities among the seedlings, saplings and mature plant showed slight variations for selected 60 woody species (Appendix 1). The total density of seedlings $\left(4790.28 \mathrm{ha}^{-1}\right)$ exceeded the total density of the saplings $\left(4219.91 \mathrm{ha}^{-1}\right)$ and the total density of mature trees and shrubs (4685.18 $\mathrm{ha}^{-1}$ ) that were included in the analysis. Ratios of seedlings to saplings $=1.135$, seedlings to mature trees and shrubs $=1.022$, saplings to mature trees and shrubs $=0.900$ also indicated as less number of saplings were recorded than that of the mature trees and shrubs. Even though the density of seedlings which is greater than that of the saplings and the mature trees and shrubs indicates as the vegetation is in a normal regeneration status, the density of saplings has not followed a similar trend. According to Alemu et al. (2011), this distribution pattern where the density of the mature trees and shrubs exceeded the total density of the saplings shows that the regeneration status of the studied vegetation is at a low state.

\section{Phytogeographical description of Dirki and Jato Vegetation}

The phytogeographical comparison is used to determine the similarity between different vegetation areas in respect of species composition. Dirki and Jato Vegetation was compared with four other previously studied vegetation with respect to its species richness (Table 7). The Vegetation shares $24.6 \%$ and $22.2 \%$ similarity with Koga woodland and the woodland vegetation extending from Lake Abaya to Chencha highlands, respectively.

The result of the comparison also showed that Dirki and Jato Vegetation shares least similarity (12.6\%) with the woodland vegetation around GamoGofa. 
The woodlands of Lake Abaya to Chencha highlands, GamoGofa and Gilgel Gibe III area are found in the southern part of Ethiopia, whereas that of Koga irrigation area is found in the northwest. The most similarity observed between the woodland around Koga and the vegetation of Dirki and Jato could be due to they share common altitudinal range and found relatively in related ecological climatic zones i.e., northwest of the country. But, the reason for the less similarity shown between the three woodlands and the vegetation under the study could be attributed to their geographical differences. This conclusion is in line with the findings given in Kebede (2010) and Dibaba et al. (2014).

Environmental variables

Variations in environmental gradients such as altitude and aspect can have remarkable effects on the distribution of plant species in vegetation. In addition to this, grazing and anthropogenic impacts (cutting, fuelwood collecting, and charcoal producing) can affect the natural distribution patterns of plant species. The overall assessment made in the vegetation revealed that anthropogenic impacts have been affecting its natural regeneration. The act of cutting made especially on small to medium sized trees and shrubs and destruction of the vegetation as a result of the demand for fuelwood and charcoal producing by the local people (Fig. 6), indicates that the vegetation has been under serious threats. The impacts were almost widely distributed in Dirki and were not limited to altitude and the sampled plots.

Grazing was another problem identified in the study area where cattle encroached into the vegetation. Accordingly, the vegetation of Dirki has been more affected particularly from the east, south and west facing sides as the vegetation is being rapidly changing into grazing land through gradual deforestation. The situation of Jato is also not far apart from this fact. Because it is found between settlements from the top and bottom, it is suffering from similar problems too.

The result obtained from the correlation analysis made (CCA) for the vegetation data and environmental variables shows the plant species were constrained by some environmental factors (altitude, aspect, human impacts and grazing (Fig. 5). This condition is consistent with the result explained in Kidane et al. (2010). Accordingly, the vegetation of Dirki and Jato sites has been highly disturbed from grazing at lower altitudinal ranges than relatively at higher altitudes. However, the effect of aspect might have been overweighed due to the north-facing part of Dirki has been bordered by a river that protects the vegetation relatively from grazing and agricultural expansion.

\section{CONCLUSION}

Dirki and Jato Vegetation have diverse structural forms which can be explained by density, height, DBH, frequency, basal area and IVI distributions. Density ha $^{-1}$ of the woody species used in the analysis was more concentrated in the lower DBH size class. Species like Clausena anisata, Maytenus arbutifolia and Premna schimperi attained the highest value of IVI due to their highest relative density even though most of their individual plants were included in the lower DBH classes. In contrary to this, Acacia abyssinica and Ficus vasta which have lower relative density could get higher value IVI due to the highest value of their relative dominance (basal area).

Dependence of the local people for collecting fuelwood, charcoal production, the requirement of different materials and grazing is highly affecting the diversity and size of the vegetation of Dirki and Jato vegetation (Fig. 6). Some plant species like Ficus sur, Cordia africana, Apodytes dimidiata, Acacia abyssinica, Ficus mucuso and few others were not represented by either seedlings or saplings while Albizia schimperiana, Allophylus macrobotrys, Bersama abyssinica, Celtis africana and few other species were represented by less number of seedlings and saplings than mature plants. However, species such as Bridelia micrantha, Calpurnia aurea, Clausena anisata, Myrsine africana, Premna schimperi and others were represented by more numbers of seedlings and saplings than mature plants and thus they were in a good regeneration status.

\section{ACKNOWLEDGEMENT}

The authors express their deepest gratitude to Addis Ababa University in general and the Department of Plant Biology \& Biodiversity Management specifically for facilitating the processes needed for the study; for facilitating the financial supplements required for the research. They also acknowledge the National Herbarium of Addis Ababa University as well as Cheliya and Ilu districts of West Shewa Zone for facilitating the necessary conditions needed to conduct the study. 


\section{REFERENCES}

Abdena F (2010) Floristic Composition and Structure of Chato Natural Forest in Horro Guduru Wollega Zone of Oromia Region, west Ethiopia, Thesis. Addis Ababa University, Addis Ababa, Ethiopia.

Adugna F (2010) Impact Assessment of Dam Construction on Floristic Diversity: A case of Gilgel Gibe III Hydroelectric Dam, southwestern Ethiopia, Thesis. Addis Ababa University, Addis Ababa, Ethiopia.

Alemu A, Pretzsch J, Mohmoud TE \& Adam YO (2011) Population structure, density and natural regeneration of Boswellia papyrifera (Del.) Hochst in Dry woodlands of Nuba Mountains, South Kordofan State, Sudan. In: Conference on International Research on Food Security, Natural Resource Management and Rural Development, University of Bonn, Germany.

Alemu S (2011) Woody Species Composition, Diversity and Structural Analysis of Angada Forest in MertiWereda, Arsi Zone of Oromia Region, Ethiopia. Thesis, Addis Ababa University, Addis Ababa, Ethiopia, Thesis. Addis Ababa University, Addis Ababa, Ethiopia.

Ayalew A, Bekele T \& Demissew S (2006) The undifferentiated Afromontane Forest of Denkoro in central highlands of Ethiopia: Floristic and Structural Analysis. SINET: Ethiopian Journal of Science 29: 45-56.

Bajpai O, Kushwaha AK, Srivastava AK, Pandey J \& Chaudhary LB (2015) Phytosociological status of a monotypic genus Indopiptadenia: A Near Threatened Tree from the Terai-Bhabar Region of Central Himalaya. Research Journal of Forestry 9(2): 35-47.

Bekele T (1993) Vegetation ecology of remnant Afromontane forests on the Central Plateau of Shewa, Ethiopia. Opulus Press AB, Sweden.

Demise G, Lemenih M \& Belliethanthan S (2013) Plant community types, Vegetation Structure and Regeneration Status of Remnant Afromontane Natural Forest Patch within Debrelibanos Monastery, Ethiopia. Open Science Repository Natural Resources and Conservation Article ID: e70081972.

Denu D (2006) Floristic Composition and Ecological Study of Bibita Forest (GuraFerda), Southwest Ethiopia, Thesis. Addis Ababa University, Addis Ababa, Ethiopia.

Dibaba A, Soromessa T, Kelbessa E \& Tilahun A (2014) Diversity, Structure and Regeneration Status of the Woodland and RiverineVegetation of Sire Beggo in Gololcha District, Eastern Ethiopia. Momona Ethiopian Journal of Science 6(1): 70-96.

Enkossa W (2008) Floristic Analysis of Alata - Bolale Forest In GudayaBilaWereda East Welega Zone, Oromia Regional State, West Ethiopia, Thesis. Addis Ababa University, Addis Ababa.

Friis I (1992) Forest and Forest Trees of Northeast Tropical Africa: Their natural habitats anddistribution pattern in Ethiopia, Djibouti and Somalia. Kew Bulletin Additional Series 15: 396.

Hadera G (2000) A study on the ecology and management of the Dessa forest in the northeastern escarpment of Ethiopia, Thesis. Addis Ababa University, Addis Ababa, Ethiopia.

Kassa Z, Asfaw Z \& Demissew S (2016) Plant diversity and community analysis of the vegetation around Tulu Korma project centre, Ethiopia. Tropical Plant Research 3(2): 292-319.

Kebede B (2010) Floristic Composition and Structural Analysis of Gedo Dry Evergreen Montane Forest, West Shewa Zone of Oromia National Regional State, Central Ethiopia. Star Journal 3(2): 119-134.

Kidane L, Bekele T \& Nemomissa S (2010) Vegetation Composition in Hugumbirda-Gratkhassu National Forest Priority Area, South Tigray. Momona Ethiopian Journal of Science 2(2): 27-48.

Lamprecht H (1989) Silviculture in the Tropics: Tropical Forest Ecosysytem and their Tree Species possiblties and methods for their long-term utilization. Deutsche Gesellschaft für Technische Zusammenarbeit, University of Michigan.

Mekonnen A (2009) Impact of dam construction on plant species Composition and Diversity: the case of Koga Irrigation Dam, northwestern Ethiopia, Thesis. Addis Ababa University, Addis Ababa, Ethiopia.

Moges Y, Eshetu Z \& Nune S (2010) Ethiopian forest resources: Current status and future management options. In: View of Access to Carbon Finances. Ethiopian Climate Research and Networking, and The United Nations Development Programme (UNDP), Addis Ababa, Ethiopia.

NBSAP (2005) National Biodiversity Strategy and Action Plan. Addis Ababa, Ethiopia.

NMA (2015) Data of Rainfall and Temperature of twenty years (1995-2014) of Ijaji area. National Meteorological Agency, Ethiopia.

Senbeta F \& Tefera F (2001) Environmental Crises in the Abiyata-Shalla Lakes National Park. In: Imperative Problems Associated with Forestry in Ethiopia. Paper presented on $\mathrm{XI}^{\text {th }}$ Annual Conference of Biological Society of Ethiopia, February 1-2, 2001, Faculty of Science, Addis Ababa University.

www.tropicalplantresearch.com 
Senbeta F (2006) Biodiversity and Ecology of Afromontane Rainforests with Wild Coffea arabica L. Populations in Ethiopia. Ecology and Development Series No. 38.Center for Development Research, University of Bonn.

Shibru S \& Balcha G (2004) Composition, Structure and regeneration status of woody species in Dindin Natural Forest, southeast Ethiopia: An implication for conservation. Ethiopian Journal of Science and Technology 3(1): 15-35.

Soromessa T, Teketay D \& Demissew S (2004) Ecological Study of the Vegetation in GamoGofa Zone, southern Ethiopia. Tropical Ecology 45(2): 209-221.

Teketay D (2005) Seed and Regeneration Ecology in Dry Afromontane Forests of Ethiopia: I. Seed production population structures. Tropical Ecology 46(1): 29-44.

Tekle K, Backeus I, Skuglund J \& Woldu Z (1997) Vegetation on hill slopes of Wello, Ethiopia: Degradation and regeneration. Nordic Journal of Botany 17(5): 483-493.

Van der Maarel E (1979) Transformation of cover-abundance values in phytosociology and its effects on community similarity. Vegetation 39: 97-114.

Wana D (2002) Plant Communities and Diversity Along Altitudinal Gradients from Lake Abaya to ChenchaHiglands, Thesis. Addis Ababa University, Addis Ababa, Ethiopia.

Woldu Z \& Backeus I (1991) The shrub land vegetation in Western Shewa, Ethiopia and its possible recovery. Journal of Vegetation Science 2: 173-180.

Woldu Z (2012) Comprehensive Analysis of Vegetation and Ecological Data Analysis, Basics, Concepts and Methods. Press AAU, Addis Ababa.

Yeshitela K \& Bekele T (2002) Plant community analysis and ecology of Afromontane transitional rainforest vegetation of southern Ethiopia. SINET: Ethiopian Journal of Science 25(2): 155-175.

Yineger H, Kelbessa E, Bekele T \& Lulekal E (2008) Floristic Composition and Structure of the Dry Afromontane Forest at Bale Mountains National Park, Ethiopia. Ethiopian Journal of Science 31(2): 103120.

\section{Supporting information}

Appendix 1: Regeneration status of selected woody species in Dirki and Jato Vegetation. 
Tadesse et al. (2018) 5(1): 61-76

Appendix 1: Regeneration status of selected woody species in Dirki and Jato Vegetation.

\begin{tabular}{|c|c|c|c|c|c|}
\hline Species & Seedlings & Saplings & MW & TD & $\% \mathrm{TD}$ \\
\hline Acacia abyssinica Hochst. ex Benth & 0 & 0 & 50.46 & 50.47 & 0.37 \\
\hline Albizia schimperiana Oliv. & 38.46 & 18.98 & 114.3 & 171.76 & 1.25 \\
\hline Allophylus macrobotrys Gilg & 3.70 & 3.70 & 22.69 & 30.09 & 0.22 \\
\hline Apodytes dimidiata E. Mey. ex Am. & 0 & 0 & 4.63 & 4.63 & 0.03 \\
\hline Bersama abyssinica Fresen. & 66.20 & 48.61 & 157.4 & 272.22 & 1.99 \\
\hline Bridelia micrantha (Hochst.) Baill. & 2.78 & 12.04 & 11.57 & 26.39 & 0.19 \\
\hline Calpurnia aurea (Ait.) Benth. & 750.93 & 453.24 & 358.3 & $1,562.5$ & 11.41 \\
\hline Celtis africana Buerm.f. & 2.31 & 2.31 & 20.83 & 25.46 & 0.19 \\
\hline Chionanthus mildbraedii (Gilg \& Schellenb.) & 0 & 0 & 6.02 & 6.02 & 0.04 \\
\hline Clausena anisata (Willd). Benth. & 937.96 & 690.28 & 822.7 & $2,450.9$ & 17.90 \\
\hline Combretum molle R. Br. ex G.Don & 19.91 & 26.85 & 54.17 & 100.93 & 0.74 \\
\hline Combretum paniculatum Vent. & 1.39 & 1.39 & 5.56 & 8.3 & 0.06 \\
\hline Cordia africana $\mathrm{L}$. & 0 & 0 & 12.5 & 12.5 & 0.09 \\
\hline Croton macrostachyus Del. & 37.96 & 59.26 & 106.5 & 203.70 & 1.49 \\
\hline Dalbergia lactea Vatke & 7.87 & 10.19 & 26.39 & 44.44 & 0.32 \\
\hline Diospyros abyssinica (Hiern) F. White & 0 & 0.93 & 5.09 & 6.02 & 0.04 \\
\hline Dodonaea angustifolia L.f. & 6.94 & 6.94 & 4.63 & 18.52 & 0.14 \\
\hline Dombeya torrida (G.F. Gmel.) P. Bamps & 100.92 & 65.28 & 8.33 & 174.54 & 1.27 \\
\hline Dovyalis abyssinica (A. Rich.) Warb. & 11.11 & 13.89 & 15.74 & 40.74 & 0.30 \\
\hline Ehretia cymosa Thonn & 0.46 & 0.93 & 6.94 & 8.33 & 0.06 \\
\hline Ekebergia capensis Sparrm. & 0 & 0 & 5.09 & 5.09 & 0.04 \\
\hline Euclea divinorum Hien & 121.76 & 163.89 & 76.39 & 362.04 & 2.64 \\
\hline Ficus mucuso (Miq.) Miq. & 0 & 0 & 2.78 & 2.78 & 0.02 \\
\hline Ficus sur Forssk. & 0 & 0 & 5.56 & 5.56 & 0.04 \\
\hline Ficus sycomorus L. & 0 & 0 & 0.46 & 0.46 & 0.01 \\
\hline Ficus thonningii Blume & 0 & 0 & 3.70 & 3.70 & 0.03 \\
\hline Ficus vasta Forssk. & 0 & 0 & 0.93 & 0.93 & 0.01 \\
\hline Flacourtia indica (Burm.f.) Merr. & 28.24 & 31.02 & 23.15 & 82.41 & 0.60 \\
\hline Gnidia glauca Steud. ex A. Rich. & 17.59 & 24.07 & 11.11 & 52.78 & 0.39 \\
\hline Grewia ferruginea Hochst.ex A. Rich & 106.02 & 47.69 & 200 & 353.70 & 2.58 \\
\hline Hymenodictyon floribundum (Hochst. \& Steud.) Robinson & 1.39 & 1.39 & 3.24 & 6.02 & 0.04 \\
\hline Hypericum quartinianum A. Rich. & 6.02 & 11.11 & 45.37 & 62.5 & 0.46 \\
\hline Maesa lanceolata Forssk. & 164.35 & 110.65 & 246.3 & 521.30 & 3.81 \\
\hline Maytenus arbutifolia (A.Rich.) Wilczek & 165.74 & 106.02 & 493.5 & 765.3 & 5.59 \\
\hline Millettia ferruginea (Hochst.) Bak. & 31.02 & 24.07 & 106.5 & 161.57 & 1.18 \\
\hline Mimusops kummel A. DC. & 0 & 0 & 0.46 & 0.46 & 0.01 \\
\hline Myrsine africana $\mathrm{L}$. & 1057.87 & 950.93 & 37.96 & 2046.8 & 14.94 \\
\hline Nuxia congesta R.Br. ex Fresen. & 2.31 & 2.31 & 26.85 & 31.48 & 0.23 \\
\hline Olea capensis L. subsp. macrocarpa (C.H. Wright) Verdc. & 0.46 & 0.46 & 1.85 & 2.78 & 0.02 \\
\hline Olea europaea L. subsp. cuspidata (Wall.ex G.Don) Cif. & 0.93 & 2.31 & 4.17 & 7.41 & 0.05 \\
\hline Olinia rochetiana A.Juss. & 133.79 & 106.48 & 128.2 & 368.52 & 2.69 \\
\hline Osyris quadripartita Decne. & 38.43 & 68.52 & 131.9 & 238.89 & 1.74 \\
\hline Phyllanthus ovalifolius Forssk. & 34.72 & 69.44 & 62.5 & 166.67 & 1.22 \\
\hline Podocarpus falcatus (Thunb.) R.B. ex. Mirb. & 13.43 & 14.81 & 6.02 & 34.26 & 0.25 \\
\hline Premna schimperi Baker & 148.61 & 299.54 & 356.5 & 804.63 & 5.88 \\
\hline Prunus africana (Hook.f.) Kalkm. & 0 & 0 & 0.46 & 0.46 & 0.01 \\
\hline Psychotria orophila Petit & 12.04 & 13.89 & 6.02 & 31.94 & 0.23 \\
\hline Rhamnus staddo A.Rich. & 51.39 & 39.37 & 2.78 & 93.52 & 0.68 \\
\hline Rhus natalensis Krauss & 150 & 129.63 & 245.8 & 525.46 & 3.84 \\
\hline Rhus vulgaris Meikle & 16.20 & 11.57 & 107.9 & 135.65 & 0.99 \\
\hline Rothmannia urcelliformis (Hiem) Robyns & 0 & 0 & 1.85 & 1.85 & 0.01 \\
\hline Rytigynia neglecta (Hiern) Robyns & 176.39 & 172.22 & 104.2 & 452.78 & 3.31 \\
\hline Sapium ellipticum (Krauss) Pax. & 2.31 & 2.31 & 6.94 & 11.57 & 0.08 \\
\hline Schrebera alata (Hochst.) Welw. & 11.11 & 22.69 & 38.89 & 72.68 & 0.53 \\
\hline Senna petersiana (Bolle) Lock & 34.26 & 68.52 & 28.24 & 131.02 & 0.96 \\
\hline Stereospermum kunthianum Cham. & 1.39 & 2.31 & 21.76 & 25.46 & 0.19 \\
\hline Syzygium guineense (Willd.) DC. & 163.43 & 225 & 205.1 & 593.52 & 4.33 \\
\hline Terminalia macroptera Giull \& Perr. & 4.63 & 4.63 & 27.77 & 37.04 & 0.27 \\
\hline Vangueria apiculata $\mathrm{K}$. Schum. & 50.46 & 41.20 & 75.48 & 167.13 & 1.22 \\
\hline Vernonia myriantha Hook.f. & 55.09 & 37.04 & 16.67 & 108.80 & 0.79 \\
\hline Total & $4,790.3$ & $4,219.9$ & 4,685 & 13,695 & 100 \\
\hline
\end{tabular}

